\title{
Polish-German bilingualism at school. A Polish perspective
}

\author{
Hanna Pulaczewska (Regensburg)
}

\begin{abstract}
This article presents the institutional frames for the acquisition of Polish literacy skills in Germany and the maintenance of Polish-German bilingualism after the repatriation of bilingual children to Poland. These processes are examined in the context of recent developments in the European domestic job market. While the European Union has placed proficiency in several languages among its educational objectives, and foreign languages have been made obligatory school subjects in all member countries, the potential advantages of internal European migrations for producing high-proficiency bilinguals are being ignored. Bilingualism resulting from migration and biculturalism enjoys little social prestige in the host countries. In Germany, there is significant regional variation in how school authorities react to challenges posed by the presence of minority languages. In many cases, the linguistic potential of many second-generation migrants and re-emigrants gets largely wasted because of lacking interest and incentives from German and Polish institutions alike.
\end{abstract}

\section{$1 \quad$ Introduction}

The social aspects of bilingualism are shaped by a specific constellation of policies, institutional measures, and social attitudes occurring at particular times in particular societies. This social context of bilingualism includes, among other things, the assignment of values, convergence or conflict of interests of the societies representing particular languages, and the decisions and activities of governments and organisations, in particular in the field of education.

The following article discusses institutional aspects of German-Polish bilingualism and its presence in the schools. The notion bilingualism will be used here in a restricted sense, referring to bilingualism resulting from biculturalism, i. e., different languages being used in the home and in the larger society. This situation pertains to cultural-linguistic minorities, families with parents speaking a different L1, and immigrant families.

\section{Bilingualism and educational language policies of the European Union}

In the European Union, the percentage of bilingual children aged 15 is estimated at about 15 percent - from a low point below 1 percent in Northern Ireland to the highest percentage in Belgium at 34 percent. E.U. policies regulate issues pertaining to the cultivation of established national minorities, which results from the general emphasis on promoting European diversity, and this emphasis is reflected in minority and language laws in particular member countries. Promoting maintenance of languages of new immigrant communities is by far less common, and it is not eligible for E.U. funding.

The E.U.'s language policy promotes multilingualism among its citizens; it is a proclaimed educational goal that all E.U. citizens should be competent in at least two foreign languages in addition to their mother tongues. At the Barcelona European Council in 2002, E.U. leaders declared support for the idea that every child in the E.U. should be taught at least two foreign 
languages beginning at an early age. With the exception of Ireland, where foreign languages are still not compulsory at any school level, all member states have introduced foreign languages as compulsory subjects in primary schools. As the E.U. adheres to the principle of autonomy in matters of education, it does not determine which foreign languages should be taught at which level or by which means (cf. van Els 2005: 214).

One of the cornerstones of the E.U. policy framework is the concept of four freedoms, meant to bring down bureaucratic barriers to form a single European market. The freedoms should enable industry and commerce to make the most of opportunities resulting from having access to 27 countries and 480 million people. The four freedoms encompass the free movement of goods, services, capital, and workforce (people). They are enshrined in the E.C. Treaty and form the basis of the single market framework. As a result of removing formal barriers to mobility, the number of migrants within the E.U. is constantly on the rise. It is the market demand that decides whether people are going to stay in their country of origin or move to a different country; this depends on whether better career opportunities sufficiently compensate the disadvantages of living abroad. E.U. policy allows commerce and industry to move a workforce from where it lives to where it is needed. In other words, the policy endorses and normalizes the occurrence of transnational conditions in the work and the lives of its people. The number of workers translocated within E.U. borders for occupational reasons is estimated at about 13 million people.

This translocation, however, has not resulted in laws and initiatives directed towards the linguistic needs of the translocated people. While the host countries often respond to the mismatch between the school and home language of the pupils by offering more instruction in the majority language to bilingual children, heritage language teaching is less popular. Languages of new immigrant groups are seldom offered as a part of school curricula; if offered at all, they are usually dealt with in supplementary courses after school hours. Although the E.U. declares multilingualism (pertaining to the languages of its member states) to be an important educational goal, it is important to note that immigrants from an E.U. country living in another member country have few possibilities to educate their children in the language of their country of origin. Exceptions to this general rule are a few large countries whose languages had been taught abroad even before the E.U. was created: English, French, German, Italian and Spanish.

Even though formally learning a language that is spoken at one's home is by far more efficient than merely learning a foreign language at school, no E.U. funding is available for teaching the mother tongue to sizable new immigrant communities, such as the Poles in Germany and the U.K., or the Romanians in Italy and Spain.

The only European country that grants every child the right to be taught his or her mother tongue at school is Sweden, provided the parents decide so. When a heritage language is taught and learned as a subject, it is treated on an equal level with all other subjects; there is a curriculum, marks, and fixed criteria for grading. However, children only receive one lesson in a week. An example of another socially-integrative solution is provided by France, where so-called international sections in some schools located in big cities can be chosen alternatively to other compulsory-elective courses. The courses embrace both language and culture, and take several hours per week. They are addressed to both pupils with migration background and native-born French. It should help the immigrant children to integrate into the French educational system, as well as enable them to possibly go back to their countries of origin and easily readjust to the educational systems in those countries. The French pupils should profit from the native skills of L1 speakers and achieve high language proficiency. The percentage of L1 speakers in such courses has been fixed at between 25 and 50 percent. According to French educational authorities, this ratio should provide an optimal learning 
environment to children learning the language of the course as L2, and truly enable them to familiarize themselves with the culture in question.

\section{$3 \quad$ Attitudes towards immigrant languages among monolingual Germans}

Starting in the $1970 \mathrm{~s}^{1}$, heritage language teaching was introduced in schools in a number of Western European countries, including Germany, in order to facilitate a return to the country of origin for the contract workers. The goal of these courses was to afford children a chance to easily readjust to life in the country of re-emigration. Once it became clear that contract workers were not going back, the need for heritage language teaching has been viewed from a different perspective. Heritage languages are frequently viewed, both by the majority speakers and policy makers, not only as being useless, but even as obstacles to individual integration, a threat to national identity and learning deficits rather than valuable assets.

Discussing the social attitudes to minority languages in the United States in the late $20^{\text {th }}$ century, Ruiz (1988) observed a large discrepancy between the attitudes towards the maintenance of so-called ethnic (heritage, community) languages and learning/teaching foreign, non-ethnic languages, in that the latter were by far more valued by monolingual speakers of English. Essentially, while foreign language learning was regarded as an elitist activity and viewed as an enhancement of social power, ethnic language maintenance was, according to Ruiz, viewed as sentimental folk activity with low individual and societal value.

The following factors have been postulated as sources of this low esteem for ethnic language teaching:

- Emphasis on literacy: reading and writing are the main language skills practiced in traditional foreign language teaching and enjoy high prestige, as they are indications of formal education and high social status, while ethnic speakers excel mainly in oral language skills.

- Ethnic languages are perceived as indications of economic, social and educational weakness.

- Ethnic languages are often viewed as a social threat to integration, ethnic language maintenance as a vehicle of separatism and disloyalty.

- Foreign languages do not lead to diglossia, which is viewed as being undesirable.

- Ethnic language maintenance is often viewed as an obstacle to learning English.

- The concepts of standard vs. vernacular language: ethnic languages are often dialects used in oral communication and different from standard written dialects.

- Individualism as the main cultural value in the U.S.: while foreign language learning is an individual initiative and, as such, highly valued, language maintenance is a group activity.

While the last point is largely culture-specific, the first five of these tendencies can also be observed in present-day Germany among the monolingual, mono-cultural part of the population. They largely determine, and are in turn co-determined by language policies related to languages of minority communities. Such policies include the sort and amount of teaching offered, and the public means directed towards an enhancement of competence in the language of the home. The scarcity of these means corresponds to the low prestige of immigrant communities caused by the economic weakness of migrants in the host country and

\footnotetext{
${ }^{1}$ A 1977 directive of the European Community prescribed the facilitation of possible reintegration of children of migrant workers into their member states of origin.
} 
the economic weakness of their countries of origin. Again, this neither pertains to immigrants from economically stronger countries nor their national languages.

While a systematic study of social attitudes towards bilingualism (as a consequence of biculturalism) in Germany has yet to be conducted and is highly desirable, the opinion that bilingualism is blocking societal integration and is a cause of underachievement at school can be encountered even among teachers and professionals who advise parents in matters of upbringing and education (e. g., speech therapists and paediatricians). ${ }^{2}$ An unfriendly attitude has also been voiced publicly by politicians, demonstrating to what degree voicing an opinion on language issues is regarded as an activity not requiring any expert knowledge - where common sense is a sufficient guide. To name one example, in 2007 Hessen's Prime Minister Roland Koch declared emphatically: "If someone stays in Germany for good, his homeland must become Germany. And it is in the language of the homeland that one starts to bring his children up." Whoever nurses his child only in the "past mother tongue" and expects from kindergarten to teach them German, "games away the child's prospects for the future". ${ }^{3} \mathrm{~A}$ similar attitude can be observed in institutional decision-making; for instance, in 2008, a Polish father lost a case against the Jugendamt (an office responsible for matters involving minors) which forbade him to communicate in Polish with his two daughters from a divorced marriage (the communication took place on the Jugendamt's premises, in the presence of an official). ${ }^{4}$ The Jugendamt justified its decision by arguing that it was not in the best interest of the children to communicate with their father in Polish, as they were growing up and attending schools in Germany. Sometimes restrictions are also put on the spontaneous use of the L1 among children from the same L1 community in public care facilities, such as nurseries and kindergartens; this stigmatizes speaking the L1, marking it as socially undesirable behavior, and thus undermining children's interest in maintaining the language. ${ }^{5}$

A combination of immigrant parents' L1 attrition, or attempts to restrict the usage of their L1 at home because of the perception of its low social acceptance, the parents' imperfect L2 skills, and lacking provision of formal teaching of the home language leads frequently to socalled semilingualism in children (see Cummins 2000). This, in turn, confirms the preexisting opinions about the detrimental effect of bilingualism on educational achievement.

At the same time, an interview-based survey conducted by graduate students of the University of Regensburg in 2008 demonstrated clearly that no detrimental effect was anticipated by German monolinguals in the case of German-English bilingualism-biculturalism; the prestige of the home language seems to be crucial in making such judgments.

Obviously, a very strong indicator of the prestige of a language, and at the same time a factor that influences this prestige, is whether it is included in the choice of languages taught as subjects at school. Here, it is notable that although the Turkish minority in Germany amounts to more than 2 million people, Turkish is scarcely included in course offerings. The compulsory-elective offerings for pupils in secondary schools typically includes Latin, English, French and Spanish, while in some states a school can apply for choosing another

\footnotetext{
2 Sources: participating observation in a clinic for speech therapy, conversations with parents of bilingual children.

3 "'Wer dauerhaft in Deutschland bleibt, dessen Heimat muss Deutschland werden. Und man beginnt in der Sprache seiner Heimat, Kinder groß werden zu lassen', sagte er am Samstag. Wer sie drei Jahre nur in der vergangenen Muttersprache aufziehe und dann vom Kindergarten erwarte, dass sie deutsch lernten, 'der verspielt die Zukunftschancen seines Kindes"'. (Koch 2007)

4 Hamburger Abendblatt 2011: "'Aus pädagogisch-fachlicher Sicht ist anzumerken, dass es im Interesse der Kinder nicht nachvollziehbar ist, dass die Zeit des begleiteten Umgangs in polnischer Sprache erfolgen soll.' Die Kinder würden doch in Deutschland aufwachsen." The case caused considerable outrage among the Polish community in Germany.

5 Sources: conversations with parents of bilingual children.
} 
language, too. However, such choices are made infrequently (with Russian in the lead among the additional languages offered).

When the child's home language, or the language of one of the child's parents, is frowned upon, and does not belong to the regular educational offer of German schools, some immigrant children reject their heritage languages in favor of German monolingualism.

\section{$4 \quad$ Polish pupils in Germany}

The number of first-generation Polish immigrants is estimated to be between 1.2 to 2 million people worldwide (cf. Dębowska 2007: 8). Most of them are located in countries of the European Union, including vast numbers of those who left Poland for occupational reasons after 2004, the year of Poland's accession to the E.U. As a result of the mass migration following the early opening of the British and Irish job markets, various sources estimate the number of Polish migrants on the British Isles at about 300,000 to 700,000, and that of school children at between 100,000 and 170,000.

The number of Polish pupils in German schools was reported to be about 25,000 in 2000 (cf. Sekretariat Kultusministerkonferenz 2002; a more current figure is not available). The relevance of this rather low number for evaluating the need of, and the demand for, teaching Polish at German schools seems to be very limited. About 420,000 Polish citizens (cf. Statistisches Bundesamt Deutschland 2010) and about as many with dual (Polish and German) citizenship (719,000 in 2005; ibid.) live in Germany. About 852,000 residents of Germany have or have had Polish citizenship (cf. Nagel 2009). In 2009 and 2010, the numbers of people who moved from Poland to Germany are estimated to be 123,000 and 126,000, respectively (cf. Statistisches Bundesamt Deutschland 2010, 2011). This suggests that in German schools, the current number of pupils of Polish origin - migrants who are either first or second generation - may be equal to the number of those living in Ireland and Great Britain. In North Rhine-Westphalia alone, there are 7,541 school-age children with only Polish citizenship (cf. Lander 2010). ${ }^{6}$ In the future, these children can keep in touch with Poland and their Polish heritage only if they achieve a high level of Polish language proficiency, which includes literacy.

\section{$5 \quad$ Polish at school: German institutions}

An official agreement signed in 1991 stipulates, among other things, that Polish will be taught in Germany. ${ }^{7}$ Article 25 of the Agreement reads:

\footnotetext{
6 In personal communication with the responsible ministry employee in June 2010, I obtained a different figure 9,109 pupils; the source of this discrepancy is unclear.

7 Vertrag zwischen der Bundesrepublik Deutschland und der Republik Polen über gute Nachbarschaft und freundschaftliche Zusammenarbeit, June 17, 1991:

"Artikel 20 (1) Die Angehörigen der deutschen Minderheit in der Republik Polen, das heißt Personen polnischer Staatsangehörigkeit, die deutscher Abstammung sind oder die sich zur deutschen Sprache, Kultur oder Tradition bekennen, sowie Personen deutscher Staatsangehörigkeit in der Bundesrepublik Deutschland, die polnischer Abstammung sind oder die sich zur polnischen Sprache, Kultur oder Tradition bekennen, haben das Recht, einzeln oder in Gemeinschaft mit anderen Mitgliedern ihrer Gruppe ihre ethnische, kulturelle, sprachliche und religiöse Identität frei zum Ausdruck zu bringen, zu bewahren und weiterzuentwickeln; frei von jeglichen Versuchen, gegen ihren Willen assimiliert $\mathrm{zu}$ werden. Sie haben das Recht, ihre Menschenrechte und Grundfreiheiten ohne jegliche Diskriminierung und in voller Gleichheit vor dem Gesetz voll und wirksam auszuüben."

"Artikel 22 (2) Die Vertragsparteien werden insbesondere - im Rahmen der geltenden Gesetze einander Förderungsmaßnahmen zugunsten der Angehörigen der in Artikel 20 Absatz 1 genannten Gruppen oder ihrer Organisationen ermöglichen und erleichtern, - sich bemühen, den Angehörigen der in Artikel 20 Absatz 1 genannten Gruppen, ungeachtet der Notwendigkeit, die offizielle Sprache des betreffenden Staates zu erlernen, in Einklang mit den anwendbaren nationalen Rechtsvorschriften entsprechende Möglichkeiten für den Unterricht
} 
(1) The parties to the agreement emphasize their will to provide an access to the language and culture of the respective other country to all people interested in them, and support corresponding governmental and private initiatives and institutions.

(3) The parties to the agreement assert the improvement of the possibilities for learning the language of the respective other country at schools, in tertiary education and other educational institutions. This includes striving for the establishment of schools with both languages as the medium of instruction. ${ }^{8}$

In actual practice, according to a report published by the Polish government sixteen years later, courses of Polish as a heritage language organized at German schools in 2005 involved just 2,000 children. According to this report in 2006, fewer than 7,000 children learned Polish in Germany as their mother language, at either German schools or Polish supplementary schools. The picture looks brighter if the teaching of Polish as a foreign language (available also to pupils speaking it at home, of course) is taken into account, which was evidently neglected in the previously quoted report. Yet, the number of children who learned Polish within the German education system is below 7,000 in the 2006-2007 school year (cf. Kultusministerkonferenz 2007), and the numbers have remained on the same level since then. ${ }^{9}$ At the same time, 35,456 children with a German background reportedly learned German as a heritage language in Poland in 2006 (cf. Ministerstwo Administracji i Cyfryzacji 2007). To compare, about 150,000 people in Poland claim to be members of the German minority, which suggests that most children from the German minority attended German classes at Polish schools.

These numbers substantiate the claim that course offerings concerning Polish in Germany are generally inadequate. However, the decentralization of the German educational system, which is governed locally on the state level, has made possible a diversification of approaches and different practices in different federal states. In particular states, Polish can be studied as a mother language in after-hours courses (as a supplementary mother tongue course 'muttersprachlicher Ergänzungsunterricht'; or workgroup - 'Arbeitsgemeinschaft'); as a foreign language (first, second or third) that can be selected as an examination subject to be passed for the certificate of secondary education; as a "Neigungsfach" ('optional elective subject') or an additional (fourth) foreign language not eligible for the final examination; as a "Begegnungssprache" - 'language of the encounter', where the language of the neighbor country is taught in the border regions to children without a Polish background; and finally, in some states, it is not offered at all. Obviously, the diversification on the level of particular localities is still greater, as a number of variables may impact the situation. Along with statelevel regulations, this includes the size of the local Polish-speaking population, estimated demand, availability of qualified teachers, alternative minority languages competing for means and attention, and the will and initiative of teachers and people in power.

\section{Regional diversification of language policies}

Since the responsibility for education is in the hands of state ministries, various approaches and reactions occur in response to similar developments, also in the area of mother tongue

ihrer Muttersprache oder in ihrer Muttersprache in öffentlichen Bildungseinrichtungen sowie, wo immer dies möglich und notwendig ist, für deren Gebrauch bei Behörden zu gewährleisten."

8 "(1) Die Vertragsparteien bekräftigen ihre Bereitschaft, allen interessierten Personen umfassenden Zugang zur Sprache und Kultur des anderen Landes zu ermöglichen, und sie unterstützen entsprechende staatliche und private Initiativen und Institutionen."

"(3) Die Vertragsparteien setzen sich nachdrücklich dafür ein, die Möglichkeiten auszubauen, in Schulen, Hochschulen und anderen Bildungseinrichtungen die Sprache des anderen Landes zu erlernen. Dabei wird auch die Gründung von Schulen angestrebt, in denen in beiden Sprachen unterrichtet wird."

9 This is a result of inquiries made at state ministries for education conducted in May-June 2010. 
teaching. To quote one example, following the aforementioned E.C. directive of 1977, German authorities handed down a list of so-called sending countries that included Turkey, Greece, Italy, Serbia, Croatia, Bosnia, Slovenia, Albany, Spain, Portugal, Morocco, and Tunisia. It was intended that the children of parents coming from these countries would receive help in the maintenance of their heritage languages. When it became clear that the guest workers were not going home, the very concept of the sending countries became obsolete. Due to the de-centralization of the German education system, radically different conclusions could be drawn from this very same situation in different regions. For example, Bavaria offered additional courses for the pupils from the sending countries, but abandoned this practice in 2004; until 2009, extra German lessons were offered instead to all pupils with a migration background. It was quite different in Rhineland-Palatinate, where a directive was issued in 2006 that added Russian to the list and enabled schools to apply for introducing another language if needed; the teaching of heritage languages has been continued. In North Rhine-Westphalia, a 2009 ministerial directive replaced teaching based on the list by teaching based on estimated demand for a particular language, with all heritage languages being equal - including Polish.

The table below shows the latest complete data as cited in the report by Kulturministerkonferenz (the standing committee of Ministers for Education) from October 5, 2007, for the school year 2006-2007. The figures comprise various forms of classes (compulsory-elective, elective, as a foreign language, as the mother language, and as "Begegnungssprache"). Additional, updated and more detailed data is supplied below for those federal states for which it was available.

$\begin{array}{lll}\text { Baden-Wuerttemberg } & \mathbf{2 0 0 6}-\mathbf{2 0 0 7} & \\ \text { Bavaria } & 50 & \\ \text { Berlin } & 12 & \\ \text { Brandenburg } & 470 & \\ & 2,154 & \begin{array}{l}\text { as mother tongue (grades 3-5): } 140 \\ \text { pupils, } \\ \text { as foreign language (grades 6-13): 140 } \\ \text { pupils }\end{array} \\ \text { Bremen } & 280 & \\ \text { Hamburg } & & \\ \text { Hessen } & 160 & \\ \text { Mecklenburg-Vorpommern } & 578 & \text { as mother tongue: 1,420 pupils, as } \\ \text { Lower Saxony } & 0 & \text { foreign language: 303 pupils } \\ \text { North Rhine-Westphalia } & 1,723 & \\ \text { Rhineland-Palatinate } & 61 & \\ \text { Saarland } & 0 & \\ \text { Saxony } & 1,379 & \\ \text { Saxony-Anhalt } & 0 & \\ \text { Schlezwick-Holstein } & 0 & \\ \text { Thuringia } & 0 & \end{array}$

The federal states which did not offer any Polish in 2007 have not yet reversed this policy. A rise in the number of learners of Polish occurred recently in Hamburg, where 250 pupils were enrolled in classes in the school year 2009-2010 (compared with 108 in 2005-2006), either in workgroups (grades 1-6) or as the second and third foreign language (grades 8-12); also, the ministry demonstrates remarkable involvement employing a part-time clerk dedicated to this issue. On the whole, it is the eastern states that show high numbers of Polish learners relative to their populations. This is undoubtedly due to being located close to the Polish border and having a high ratio of Polish children, as well as looking back on a history of cooperation and 
exchange, with Poland as an equal partner. In Mecklenburg-Vorpommern, 528 pupils learned Polish as a foreign language in the school year 2009-2010; in Sachsen, 1,344 and 2,195 in Brandenburg, where Polish could be studied at as many as 35 schools - as a foreign language, mother tongue, and a "Begegnungssprache". The teaching of the first foreign language in Brandenburg starts at Grade 3. State law stipulates that Polish can be selected as the first foreign language if specified personal and material conditions are fulfilled; these conditions include, among other things, that Polish is also offered at all types of secondary schools in the region in question so that learning can be continued beyond the primary level.

Another distinguished location is North Rhine-Westphalia, where, similarly to Brandenburg and, unusual for Germany in general, Polish is offered at schools of all types, including Grundschule ('primary school', comprising grades 1-4), Gymnasium (leading to the certificate of secondary education) and other types of secondary schools: Real-, Gesamt- and Hauptschule. In 2009-2010, 649 children learned Polish as a foreign language in 12 schools; apart from that, 1,501 children attended Polish supplementary mother tongue classes in 42 schools, usually for 3 hours a week, sometimes for as many as 5 hours a week. Polish learned as a mother tongue receives a separate school report, and the attendance is mentioned in the regular (main) report.

In Berlin, Polish can be learned at two Gymnasiums: Gabriele-von-Bülow-Schule and Albrecht-Dürer-Gymnasium, as well as in Robert-Jungk-Oberschule (combining the secondary school forms Hauptschule, Realschule and Gymnasium) and the private secondary school Katholische Privatschule St. Marien (a Realschule, ending with a lower certificate than a Gymnasium). In addition, there is a private bilingual primary school, Katharina-HeinrothGrundschule, that is explicitly directed towards the needs of Polish and bicultural children and parents.

In nine federal states - Bavaria, Berlin, Bremen, Brandenburg, Hamburg, MecklenburgVorpommern, Lower Saxony (on application), North Rhine-Westphalia and Saxony - Polish can be chosen as an examination subject for the certificate of secondary education.

Polish is not offered as a foreign language in Lower Saxony, Saarland, Saxony-Anhalt, Schleswig-Holstein, Thuringia, Baden-Wuerttemberg ${ }^{10}$, and Bavaria. In Rhineland-Palatinate, there were 2 pupils with Polish as the second foreign language in the school year 2009-2010 (at a Gymnasium in Ramstein-Miesenbach). Otherwise, the teaching in Rhineland-Palatinate only takes place in the form of after-hours extracurricular workgroups, of which there were eight in 2009-2010; the marks appear in the school report but are irrelevant for calculating overall school achievement (the report regulates passing students to the next grade). In BadenWuerttemberg, 59 children enrolled in that school year for workgroups at Gymnasiums; such workgroups also exist in Sachsen-Anhalt. In Bavaria, the second largest federal state after North Rhine-Westphalia, the only form of teaching Polish and other heritage languages of children with migration backgrounds are afternoon courses comprising a 45-minute lesson once a week, on the premises of an appointed school collecting pupils from the entire town or city. The groups consist of children of similar ages, with larger age differences within a group at higher levels.

\section{$7 \quad$ Polish institutions}

Since 1973, Polish embassies and consulates maintained Polish-language Saturday schools for the children of diplomats and other employees delegated to work in these institutions. The children were supposed to go back to Poland with their parents after the term of employment

\footnotetext{
${ }^{10}$ State law stipulates that it can be chosen instead of another foreign language by immigrant children who started attending a German school at grades 8 through 11, with some differences depending on the type of school, as also is the case with other mother tongues.
} 
came to an end. Accordingly, the schools were meant to enable the students to keep up with the regular Polish curriculum either in all subjects, or at least in the so-called supplementary scheme. The supplementary scheme classes included: Polish language, Polish history, Polish geography and, in higher grades, social studies. Children from the local Polish communities could also attend these schools if there were some free places left. However, the curriculum was molded according to the expectation that the children would eventually return to their country of origin; that is, it did not in any way accommodate to the local school curricula of the schools which the children attended during the week. In December 2009, the number of pupils enrolled in such schools worldwide was 13,562 (cf. Ministerstwo Edukacji Narodowej 2009).

In Germany, schools of that type were founded under the auspices of the consulates in Munich, Bonn, Hamburg, and Berlin; additional branches were also formed in Frankfurt and Nurnberg. Today, the schools continue their activities under changed circumstances. Only about one third of the Polish immigrants have plans to go back (cf. id: 8), and 95 per cent of the students have opted for the supplementary curriculum. ${ }^{11}$

In spite of the large teaching load, the six aforementioned schools have enjoyed great popularity. In the school year 2007-2008, they were attended by 1,073 students (cf. ibid.). In Munich, the demand has always been much greater than the number of students that the school can accommodate.

A grave problem of these schools has been their very poor funding by the Polish government. The schools have no buildings of their own, and in a number of cases it is their part-time headmasters who have been made responsible for finding rooms to conduct the teaching. Usually the problem has been solved through appealing to local regular schools and using their premises; this is also the case at the aforementioned German locations. Sharing facilities with other users is a serious problem because the teachers and the students cannot feel at home and furnish or decorate the rooms according to their needs. Sharing space also magnifies the serious lack of funding provided by the Polish government for the teaching of Polish to Poles abroad. With these policies, Polish authorities send a message to students that there is little value attached to the learning of Polish, and that they have little regard in general for Poles living abroad. Another related message is that of Poland as a poor cousin; this certainly does not motivate children and youth to want to keep in touch and identify with their country of origin.

Apart from these schools, there are Polish community schools, whose total number is not known exactly. In Germany, there are no fewer than 55 community schools, which were attended by at least 2,196 pupils in the 2007-2008 school year (cf. ibid.).

The prospects for consulate schools are grim: in April 2009, the Polish government proposed a plan to stop operating them (cf. ibid.). According to the initial plan, numerous schools were going to be closed by 2009, but the measure was postponed after a series of demonstrations by parents, children and students in mid-2009 (June 8 in Athens, June 13 in Brussels and Paris, June 27 in Munich). According to the plans valid in summer 2010, lyceums (grades 1012) were to be closed in September 2010; all schools were to be taken over by local parents' associations or other community groups willing to take it upon themselves till September 2011, and closed otherwise. The parents' associations were expected to find local sponsors, while the Polish government was to participate in expenses, train teachers and provide the curriculum. These plans have been reversed, at least temporarily, for some locations, as the

\footnotetext{
11 The rather grave disadvantages of the main curriculum include, along with the proliferation of subjects, the lack of coordination in mathematics: the same branches are covered in the German regular school and in the Polish supplementary school at different grades and at different times, in a different order and using different methods (from theory to practical application or the other way round).
} 
hope for community takeovers have been futile, and the closures would have caused a good deal of agitation. However, the direction has been established: eventually, teaching done by teachers should be replaced by the implementation of a cost-saving e-learning platform. ${ }^{12} \mathrm{E}-$ learning has been declared to be the ultimate, progressive and efficient solution adequate to the spirit of the times.

\section{$8 \quad$ Institutions and motivation}

Motivation has traditionally been described as being of two basic types: instrumental and integrative. Integrative motivation is characterised by the learner's positive attitude towards the target language group and the aspiration to be a member of the target language community. In instrumental motivation, the goal of learning is to gain some other social or economic reward through learning achievement; this amounts to a more functional reason for learning achievement (cf. Gardner 1982). The point of the following deliberations is that the tasks of educational institutions should not be viewed as limited to providing opportunities for learning; even more crucial is their role in providing motivation.

One deficiency of the 45-minute weekly after-school courses that are practiced at some locations (notably, in Bavaria) is the small amount of teaching and the resulting slow progress, or even lack of any visible progress after some levels. Even if children of Polish origin often reject their heritage language as a result of stigmatisation, the demand for formal teaching is high at locations where there is an established and known supply of courses in Polish language and culture. Observations suggest that extensive courses offering several hours of Polish each week are more popular than courses of low intensity. Courses comprising 3 to 5 hours a week in Hamburg, Brandenburg and North Rhine-Westphalia have attracted hundreds of school children; similarly popular are consulate schools, offering many hours of teaching. At the same time, the 45-minute-a-week after-school courses organised by the German authorities for Polish children in Regensburg only gather a handful of pupils at each of the few levels offered, where children at different ages are collected together in one group. While the correlation between the intensity of the course and the demand has not been systematically studied, it is easily conceivable that more intense learning is more attractive because it is also more effective. Visible progress is as strong a motivating factor for learning and attendance as the lack of it is a motivation killer.

The even more serious deficiency of this form of teaching, however, is that it is not integrated into the school system. If the parents request it, attendance can be mentioned in the school report, but there are no marks and no other recognition of achievement. This means that while offering courses, the school does not offer the pupils any sense of value of the work invested in attending them, and proficiency enhancement. Proficiency and literacy in Polish obviously lack recognition as an asset and a component of general education, quite unlike foreign languages included in the curriculum and on certificates. Informal discussions with teachers in Bavaria and Rhineland-Palatinate suggest that the relegation of Polish lessons to the hours when schools are mainly occupied by janitors, who are not necessarily sympathetic to late leavers busying themselves with what they regard as unimportant endeavors, is also not very motivating. Pupils can easily decipher signals of social prestige, or a lack thereof, and their motivation, as a result, is affected. ${ }^{13}$

\footnotetext{
12 To learn more about the debate around the controversial plans discussed in this section, see www.polskaszkola-monachium.info/e107_plugins/content/content.php?recent.59, accessed January 27.

13 On a personal note, my son quit such a course at the age of eleven after just a few months of attendance, on the argument that "these are not real lessons" ("bo to nie są prawdziwe lekcje") - which clearly underlines what has been articulated about the advantages of integration of such lessons into the real curriculum.
} 
The most rewarding form of learning Polish is to have lessons of Polish as a foreign language, thus giving it the dignity of a "real" subject. That these courses are superior to teaching Polish as the mother tongue was also a conclusion reached by a Polish ministerial commission that examined the situation of Polish at German schools in 2007, albeit for different reasons. ${ }^{14}$

As for integrative motivation, the consulate schools in particular give pupils of Polish backgrounds an opportunity to spend a fair amount of time together and organise extracurricular activities, enhancing group bonds. In this way, they generate integrative motivation in children by enhancing a sense of community and cultural identification through biculturalism and bilingualism. In schools run by the Poles themselves, teachers function not only as organizers of the learning process, but also as role models sharing the situation of bilingualism and biculturalism with the students.

As indicated, learning Polish in German schools as part of the curriculum, rewarded by visible recognition in the form of testing achievement, marks and school reports, provides instrumental motivation - similar to what fuels a desire to learn in other school subjects. However, it is relevant for integrative motivation, too: making Polish a school subject amounts to acknowledging the potential instrumental value of Polish by German schools that act as institutions representing the authority of the German state. Thus, Poland is visibly recognized as a partner in business, politics and cultural exchange; this, in turn, positively affects integrative motivation.

As for e-learning, even if it indeed provides necessary materials to learn Polish for pupils abroad, its role in providing motivation is negligible. Learning under such circumstances is devoid of any palpable integrative or instrumental reward. It is reduced to a lonely activity with no social value, in which children - overburdened with other, more immediately rewarding duties imposed by the school - are not likely to invest their time.

\section{Re-emigration of Polish children}

The high number of emigrants who left Poland in search of work, coupled with the economic improvement in Poland, make a huge wave of re-emigration back to Poland a very likely scenario. This flow, which has already started, also includes numerous children born or brought up in Germany. Their needs with respect to the continuation of learning German are, of course, different from those provided in the curriculum for German as a foreign language. This confronts language teachers, who have themselves learned German largely through formal instruction, with the new and partly uncomfortable situation of having native speakers of German in their classes. As speakers educated in Germany, these children show better language skills than the teacher herself in matters of pronunciation, idiom, and colloquial language. This may pose a psychological problem to the teacher, who needs to retain her authority as a teacher, without at the same time ignoring the opportunity to profit from this situation: by using the native speaker as a helper and a source of expert knowledge where it is possible and useful. A situation in which the teacher and the pupil learn from each other offers numerous pedagogical advantages. However, it is entirely new for the teacher in the Polish school. Usually, teaching is based on a model in which the teacher has higher

\footnotetext{
14 "One should also mention that a rather dynamic development of teaching Polish as the mother language was achieved in recent years in North Rhine-Westphalia (involving 1,500 children) thanks to the very positive attitude of the state authorities. Yet, it seems that this form of teaching generally has no future because it will be systematically eliminated as a result of cost-saving measures and the so-called integration policy of the German authorities. Also, in the specific German climate it is unlikely that people who left Poland as so-called ethnic Germans would have the courage to declare that their children be taught Polish as the mother language at public schools. In this situation, it is the introduction of Polish as another foreign language into schools that should be the goal, while teaching Polish as the mother language should be left to Polish organizations [...]" (Międzyresortowy Zespół do Spraw Polonii i Polaków za Granicą 2007)
} 
competence in every aspect of the subject taught than any of the pupils. An individual teacher should not be left to his or her own means when striving to work out a strategy to adapt to, and profit from, the new situation: the processes in question are predictable, analyzable and open to practical solutions. It is desirable that teachers be given a hand in the form of organised courses dealing with this situation and offering possible strategies. This would include indicating ways to reaffirm the teacher's authority in the eyes of the pupils, e. g., by making the pupils realise that language proficiency is not only about pronunciation and fluency of colloquial speech, but also other components that the teacher has mastered, such as grammar, work with texts, special vocabularies, etc. At the same time, the process of teaching should not be artificially pushed towards overemphasizing those components and skills while demeaning the value of native-like fluency.

A considerable improvement of the situation of repatriated children wishing to retain and develop their skills in German, which used to be their everyday spoken language and the language of the school, would be the introduction of bilingual classes with bilingual teachers. This is possible if many students with a Polish background become members of the teaching profession in Germany, provided that they first acquire competence and literacy in Polish by attending Polish classes offered at German schools (and, of course, that they will be willing and given opportunities to teach in Poland).

All these considerations belong to the complex issues of transnational schooling - a concept of adequate teaching that would meet the needs of bicultural children and is based on the cooperation of education systems in countries affected by cross-border movements. Transnational schooling is a requirement in the present day, and detrimental effects can be expected if it is not offered the attention it deserves.

\section{References}

Cummins, Jim (2000): Language, power, and pedagogy. Bilingual children in the crossfire. Clevedon, UK/Buffalo: Multilingual Matters.

Dębowska, Olga (2007): Migracje - wyniki aktualnych badań i analiz. Kraków: Małopolskie Obserwatorium Rynku Pracy i Edukacji.

Els, Theo van (2005): "Multilingualism in the European Union." International Journal of Applied Linguistics 15/3: 263-281.

Gardner, Robert C. (1982): "Language attitudes and language learning". In: Ryan, Ellen B./Giles, Howard (eds.): Attitudes towards language variation. London: Edward Arnold: 132-147.

Hamburger Abendblatt, May 27, 2011: "Wojciech Pomorski - und sein Kampf gegen die Stadt Hamburg". http://www.abendblatt.de/hamburg/polizeimeldungen/article1905530/ Wojciech-Pomorski-und-sein-Kampf-gegen-die-Stadt-Hamburg.html, accessed March 03, 2014.

http://www.polska-szkola-monachium.info/e107_plugins/content/content.php?recent.59, accessed September 27, 2011.

Koch, Roland (2007): "Ausländer sollen mit Kindern deutsch reden". Focus April 28, 2007.

Lander, Bettina (2011): Bildungsreport Nordrhein-Westfalen 2010. Information und Technik Nordrhein-Westfalen, Geschäftsbereich Statistik. (= Statistische Analysen und Studien 68). https://webshop.it.nrw.de/gratis/Z089\%20201054.pdf, accessed January 29, 2014.

Międzyresortowy Zespół do Spraw Polonii i Polaków za Granicą (ed.) (2007): Polityka Państwa Polskiego wobec Polonii $i$ Polaków za granica. http://www.paulkostecki.com/Fakty_polonijne/raport_KPRM.pdf, accessed January 29, 2014.

Ministerstwo Administracji i Cyfryzacji (ed.) (2007): Raport dotyczacy sytuacji mniejszości narodowych i etnicznych oraz jezyka regionalnego w Rzeczypospolitej polskiej. Warszawa. 
http://prohumanum.org/wp-content/uploads/2008/03/raportmniejszosci.pdf, accessed January 29, 2014.

Ministerstwo Edukacji Narodowej (ed.) (2009): Program rozwoju oświaty polskiej za granica $i$ oświaty polonijnej na lata 2009-2011. Warsaw. http://www.polskaszkola.pl/file.php/1/moddata/forum/32/25/plan_dzialan_projekt.pdf , accessed January 29, 2014.

Nagel, Sebastian (2009): Zwischen zwei Welten. Kulturelle Strukturen der polnischsprachigen Bevölkerung in Deutschland. http://www.ifa.de/fileadmin/pdf/studien/polonia2009.pdf, accessed January 29, 2014.

Ruiz, Richard (1988): "Bilingualism and bilingual education in the United States." In: Bratt Paulson, Christina (ed.): International handbook of bilingualism and bilingual education. New York, Greenwood: 539-560.

Sekretariat der Kultusministerkonferenz (ed.) (2002): Ausländische Schüler und Schulabsolventen 1991 bis 2000. Bonn. (= Statistische Veröffentlichungen der Kultusministerkonferenz 163). http://www.kmk.org/fileadmin/veroeffentlichungen_beschluesse/2002/2002_10_01Auslaendische-Schueler-91-00.pdf, accessed January 29, 2014

Sekretariat der Kultusministerkonferenz (ed.) (2007): Zur Situation des Polnischunterrichts in der Bundesrepublik Deutschland. Bericht der Kultusministerkonferenz vom 22.08.1991 in der Fassung vom 05.10.2007.

Statistisches Bundesamt Deutschland (ed.) (2010): "Level of immigration into Germany increasing again in 2009". (= News Release 185, May 26, 2010). https://www.destatis.de/EN/PressServices/Press/pr/2010/05/PE10_185_12711.html, accessed January 29, 2014.

Statistisches Bundesamt Deutschland (ed.) (2011): "Migrations in 2010. Number of people migrating to Germany markedly higher". accesed January 30, 2014. (= News Release 180, May 09, 2011). https://www.destatis.de/EN/PressServices/Press/pr/2011/05/PE11_180_12711.html,

Vertrag zwischen der Bundesrepublik Deutschland und der Republik Polen über gute Nachbarschaft und freundschaftliche Zusammenarbeit, June 17, 1991. http://www.auswaertigesamt.de/cae/servlet/contentblob/574756/publicationFile/152277/DeutschPolnischer_Nachbarschaftsvertrag.pdf, accessed January 29, 2014. 